\title{
CULTURAL STUDIES: NOWA PERSPEKTYWA DLA NAUKI O STOSUNKACH MIĘDZYNARODOWYCH?
}

Główny cel niniejszego artykułu polega na ukazaniu, w jaki sposób tezy składające się na stosunkowo młodą dyscyplinę, której prawie nikt nie łączy obecnie z tradycyjnie pojmowaną nauką o stosunkach międzynarodowych, mogą w sposób istotny wzbogacić jej możliwości eksplanacyjne. Dziedzina, o której tu mowa, są tzw. studia kulturowe (cultural studies), na gruncie polskiej humanistyki równie często, co niepoprawnie utożsamiane z szeroko rozumianym kulturoznawstwem. Stanowiąc integralną część postmodernizmu oraz opierając się na konstruktywistycznym modelu poznawczym, studia kulturowe zdołały wypracować specyficzne, w znacznym stopniu odbiegające od utartych schematów, sposoby rozumienia i badania kategorii władzy. Problematykę dominacji ujmują one nie tyle przez pryzmat ekonomicznej czy też militarnej przewagi, lecz w odniesieniu do wytwarzanych społecznie reprezentacji i tożsamości. Podobne podejście niewiele ma wspólnego z tradycyjnym postrzeganiem władzy jako domeny sformalizowanych instytucji politycznych - polityczna jest tutaj cała kultura w swej złożonej istocie, głównym zaś nośnikiem relacji panowania staje się wytwarzana i upowszechniana na jej temat wiedza.

Czy jednak tak zarysowana perspektywa może znaleźć szersze zastosowanie w analizie problemów typowych dla teorii stosunków międzynarodowych? Na zadane w ten sposób pytanie chcemy udzielić odpowiedzi zdecydowanie twierdzącej, zaznaczając jednocześnie, iż krytyczne nastawienie wielu internacjologów względem podstawowych założeń postmodernizmu, mimo iż motywowane szlachetnym pragnieniem zachowania „czystości” dyscypliny, wpędza ją w szkodliwy, konserwatywny marazm. Aby pokazać, jak wiele nauka ta zyskać może otwierając się na dziedziny pokroju studiów kulturowych, posłużymy się dokonaną przez Edwarda Saida charakterystyką dyskursu orientalistycznego oraz jej wkładem w analizę problematyki kolonializmu i postkolonializmu. Zanim to jednak nastapi, dookreślić musimy samą istotę cultural studies, w owym zaś dążeniu nie unikniemy pytań zarówno o postmodernizm, jak i specyfikę konstruktywistycznego modelu percepcji świata społecznego. Przeprowadzenie usystematyzowanej refleksji na tym polu pozwoli nam zrekonstruować podstawowe kategorie pojęciowe, w świetle których koncepcja Saida uzyska niezbędną transparentność.

\section{KONSTRUKTYWIZM - POSTMODERNIZM - STUDIA KULTUROWE: KWESTIE DEFINICYJNE}

Czytelne nakreślenie istoty studiów kulturowych wymaga uprzedniego zdefiniowania ich konstruktywistycznego charakteru. W tym celu posłużymy się zaproponowa- 
nym przez Andrzeja Zybertowicza rozróżnieniem dwóch alternatywnych modeli poznania, których najważniejsze wyznaczniki zestawione zostały w tabeli 1 .

Tabela 1

\section{Dwa modele poznania według A. Zybertowicza}

\begin{tabular}{||l|l||}
\hline \multicolumn{1}{|c|}{ Obiektywistyczny model poznania } & \multicolumn{1}{|c|}{ Konstruktywistyczny model poznania } \\
\hline $\begin{array}{l}\text { Rzeczywistość jest obiektywna i zewnętrzna względem } \\
\text { podmiotu poznania - jest czymś, co należy odkryć }\end{array}$ & $\begin{array}{l}\text { Przekonanie o istocie Rzeczywistości zawsze konstru- } \\
\text { owane jest przez praktyki kulturowe w danym kontekś- } \\
\text { cie społeczno-historycznym }\end{array}$ \\
\hline $\begin{array}{l}\text { Prawda jest kwestią prawidłowego odzwierciedlenia } \\
\text { Rzeczywistości i uzyskania poprawnej Wiedzy na jej } \\
\text { temat }\end{array}$ & $\begin{array}{l}\text { Prawda i Wiedza są sprawą (ukrytego) konsensusu } \\
\text { w kwestii tego, jak należy je definiować }\end{array}$ \\
\hline $\begin{array}{l}\text { Kategorie semantyczne języka pośredniczą w adekwat- } \\
\text { nym opisywaniu Rzeczywistości }\end{array}$ & $\begin{array}{l}\text { Kategorie semantyczne języka konstruują Rzeczywis- } \\
\text { tość, gdyż nie istnieje żaden poza-językowy sposób jej } \\
\text { postrzegania }\end{array}$ \\
\hline $\begin{array}{l}\text { Istnieje jeden poprawny opis Rzeczywistości, do któ- } \\
\text { rego należy dojść wytwarzając Wiedzę }\end{array}$ & $\begin{array}{l}\text { Każda Wiedza jest zaledwie jednym z wielu możliwych } \\
\text { opisów Rzeczywistości }\end{array}$ \\
\hline $\begin{array}{l}\text { Wiedza naukowa jest ideologicznie neutralna, dlatego } \\
\text { należy traktować ją jako uprzywilejowany sposób opi- } \\
\text { sywania świata }\end{array}$ & $\begin{array}{l}\text { Zadna forma wiedzy nie jest wolna od ideologicznych } \\
\text { uwarunkowań. Nauka jest nie bardziej obiektywna, niż } \\
\text { metafizyka i magia }\end{array}$ \\
\hline $\begin{array}{l}\text { Podstawowe pytanie: jaka jest Prawda? } \\
\text { Podstawowe pytanie: dlaczego w danych okoliczno- } \\
\text { ściach grupa ludzi jest skłonna uznać coś za Prawdę? }\end{array}$ \\
\hline \hline
\end{tabular}

Źródło: Opracowanie własne na podstawie: A. Zybertowicz, Przemoc i poznanie. Studium z nie-klasycznej socjologii wiedzy, Toruń 1995, s. 59-63.

Podstawę modelu obiektywistycznego (zwanego również realistycznym, empirystycznym lub pozytywistycznym) stanowi przekonanie o wyraźnej ontologicznej odmienności podmiotu (jednostka czy raczej jej wiedza), przedmiotu (obiektywna rzeczywistość) oraz języka w procesie poznawczym. Poprzez wytwarzanie coraz bardziej rzetelnych typów wiedzy, podmiot stopniowo przybliża się do odkrycia właściwości zewnętrznego, ahistorycznego przedmiotu. Pomiędzy nimi i za pośrednictwem języka (traktowanego tutaj jako swoiste narzędzie odtwarzania) zachodzi powiązanie epistemologiczne ${ }^{1}$, o poprawności którego mówić możemy, ,gdy między wiedzą podmiotu a właściwościami przedmiotu występuje relacja korespondencji, gdy kształt bytu jest reprezentowany w treściach wiedzy. Zastosowania ma tu klasyczna definicja prawdy. Wiedza uobecnia prawdę, która znajduje się gdzieś na zewnątrz, poza nią"2.

Model konstruktywistyczny (zwany też relatywistycznym, nominalistycznym lub pragmatycznym) dowodzi natomiast, że ,wiedza postrzegana jako obiektywna nie jest neutralna. Ani społecznie, ani indywidualnie, ani moralnie, ani materialnie. Że niezależ-

1 „Jest to układ, w którym istnieją traktowane jako osobne i względem siebie w zasadzie niezależne: podmiot, przedmiot i wiedza (język). Przedmiotowi przypisywane są obiektywne właściwości, które podmiot - jeśli będzie postępował właściwie - może poznać, tzn. znaleźć się w posiadaniu wiedzy prawdziwej. Podmiot przyjmuje, że przedmiot może być poznany, tj. modelowany za pomocąjęzyka. Poznanie zachodzące w obrębie takiego układu ma charakter pojęciowy”. A. Zybertowicz, Przemoc i poznanie. Studium z nie-klasycznej socjologii wiedzy, Toruń 1995, s. 209.

2 Ibidem, s. 74. 
nie od tego, na ile pewne systemy wiedzy można uznać za - w jakimś sensie - obiektywne, bardzo często stanowią one tylko jedną z możliwych interpretacji danego kontekstu rzeczywistego [...]. Konstruktywizm wątpi, czy istnieją fakty, które w jakimkolwiek dostępnym dla nas, ostatecznym lub absolutnym sensie są niepodważalne, konieczne i uniwersalne [...], to, co jedni uznają za fakty, inni mogą ignorować, de-montować, modyfikować i konstruować po swojemu. [...] Konstruktywizm nie zamyka oczu na fakty, ale stara się dostrzegać ich historyczny, przejściowy charakter"”3. Zostają tutaj zanegowane podstawowe cechy obiektywizmu: dualizm ontologiczny podmiot-przedmiot, empiryzm, reprezentacjonizm. „Konstruktywizm odrzuca nie tylko tezę, że wiedza stanowi coś w rodzaju odbicia, odwzorowania świata, który swą własną naturą przesądza jej kształt. Odrzuca też tezę, że w ogóle można prawomocnie mówić cokolwiek o świecie poza samą wiedza, poza kulturą [...]”4. W ten sposób filozofia wiedzy przekształca się w ogólną ontologię bytu społecznego. Nie bada się już relacji między wiedzą a światem, lecz między wiedzą a społeczeństwem - tylko bowiem odtworzenie takich powiązań pozwala odpowiedzieć na pytanie, dlaczego w danej zbiorowości świat rozumiany jest w taki, a nie inny sposób? Jednocześnie negacji ulega wiara w prawdę absolutna, która - jak dowodzi Ludwik Fleck - nie jest „„względna" lub nawet »subiektywna« w popularnym znaczeniu tego słowa. Jest ona zawsze, lub prawie zawsze, w pełni zdeterminowana w obrębie jakiegoś stylu myślowego. Nie można powiedzieć, że ta sama myśl jest prawdziwa dla $A$, zaś dla $B$ jest fałszywa. Jeśli A i B należą do tego samego kolektywu myślowego, to myśl jest dla obu albo fałszywa, albo prawdziwa. Jeśli natomiast należą do różnych kolektywów, to nie jest to ta sama myśl, ponieważ musi być ona dla jednego z nich niejasna albo jest przezeń inaczej rozumiana" .

Prawda jest tedy konstruowana (a nie - odkrywana) przez język, a konkretniej - przez słownik, czyli specyficzną logikę „,wiązania” określonych kategorii semantycznych w spójny opis rzeczywistości. Alternatywne słowniki, których istnieć może nieskończenie wiele, „klasyfikują obiekty i konfigurują doświadczenie społeczne w określony sposób - wspól-tworzą swoje światy, sugerują niedowolne rozwinięcia empirycznych zainteresowań”, Pogląd ów, zasadzający się na przekonaniu, iż „słowo może aktywnie formować świat, nadawać mu kształt, czynić oczekiwane lub nie-oczekiwane rozróżnienia, wyodrębniać, powoływać do istnienia, ocalać od zapomnienia lub spychać na margines uwagi”" zgodny jest z tzw. hipotezą Sapira-Whorfa, zakładająca, iż „we wszystkich językach istnieją wyspecjalizowane i rozbudowane słowniki, których celem jest opis i zrozumienie istotnych cech życia społecznego i kulturowego"8 , a użytkownicy poszczególnych systemów językowych żyją niejako w odrębnych światach, czy raczej - odrębnych opisach świata, które nie muszą być wzajemnie przekładalne. Jak zauważa Benjamin Lee Whorf, „dzielimy świat na części, porządku-

3 Ibidem, s. 112-114.

4 Ibidem, s. 99.

5 Ibidem, s. 131.

${ }^{6}$ Ibidem, s. 126.

Ibidem, s. 142.

8 E. Baldwin, B. Longhurst i in., Wstęp do kulturoznawstwa, Poznań 2007, s. 71. 
jemy go za pomocą pojęć, przypisujemy mu sens w określony sposób, ponieważ jesteśmy sygnatariuszami umowy, by uczynić to tak właśnie, a nie inaczej: umowy, która obowiązuje w naszej społeczności językowej i którą skodyfikowano we wzorcach naszego języka"".

Należy jednocześnie zauważyć, iż konstruktywizm nie zakłada, jakoby jakieś zewnętrzne względem człowieka środowisko nazywane „światem” nie istniało (byłby on wówczas po prostu odmianą solipsyzmu, podczas gdy w istocie bliżej mu do postawy agnostycznej) - jego reprezentanci twierdzą jedynie, że nie istnieje obiektywna wiedza o świecie, świat zaś może być dla człowieka tylko tym, co człowiek postrzega jako „świat” z perspektywy wiedzy, którą posiada. Jak podkreśla Richard Rorty, ,należy odróżnić twierdzenie, że świat jest na zewnątrz, od twierdzenia, że prawda jest na zewnątrz. Powiedzieć, że świat jest na zewnątrz, że nie wytworzyliśmy go, to tyle, co stwierdzić [...], iż większość przedmiotów w czasie i przestrzeni jest rezultatem przyczyn różnych od stanów ludzkiego umysłu. Powiedzieć, że prawda nie jest na zewnątrz, to po prostu tyle, co stwierdzić, że tam, gdzie nie istnieją zdania, nie ma prawdy, że zdania są elementami ludzkich języków, a języki ludzkie to twory człowieka. Prawda nie może być na zewnątrz - nie może egzystować w oderwaniu od ludzkiego umysłu - ponieważ zdania nie mogą w ten sposób egzystować ani być na zewnątrz. Świat jest na zewnątrz, nie ma tam jednak opisów świata. Tylko opisy świata mogą być prawdziwe bądź fałszywe" ${ }^{\text {"10 }}$.

Dowodząc ograniczeń modelu obiektywistycznego, Richard Devetak przytacza zaproponowany przez Maxa Horkheimera podziałem na ,teorię rozwiązującą problemy” oraz „teorię krytyczną”. Pierwsza ma charakter pozytywistyczny oraz cechuje się ukrytą legitymizacją i reifikacją istniejącego porządku, który przedstawia jako zupełnie naturalny - koncentruje się więc jedynie na maksymalnym usprawnieniu jego funkcjonowania. Przykładowo, managerowie zastanawiają się, w jaki sposób zwiększyć zyskowność przedsiębiorstwa na kapitalistycznym rynku, ale nie przyjdzie im pewnie do głowy zapytać, czy nie dałoby się zaproponować jakiejś lepszej alternatywy dla samego rynku kapitalistycznego? Osoby myślące w podobny sposób nie zdają sobie sprawy z tego, jak bardzo ich rzekomo „naturalna”, a przez to „neutralna” wizja świata osadzona jest w specyficznych układach kontekstów i interesów. Teoria krytyczna stara się rekonstruować takie uwarunkowania i wykraczać poza utarte ramy myślenia o rzeczywistości. W odniesieniu do kapitalizmu (aby trzymać się poprzedniego przykładu) próbuje wskazać, w świetle jakich procesów historycznych określona grupa ludzi uznała ów wariant ekonomiczny za uniwersalny, komu przynosi on zyski, a komu - straty i czy kwestii produkcji oraz dystrybucji dóbr nie można rozwiązać w inny sposób? ${ }^{11}$.

W podobnym tonie wypowiada się R. Rorty, dokonując rozróżnienia pomiędzy dyskursem normalnym (epistemologicznym) i nienormalnym (hermeneutycznym). „Ogólnie rzecz biorąc, dyskurs normalny to taki dyskurs, w którym obowiązuje uzgodniony

9 Cyt. za: ibidem, s. 72.

10 R. Rorty, Przygodność, ironia i solidarność, Warszawa 2009, s. 23-24.

11 R. Devetak, Teoria krytyczna, w: Teorie stosunków międzynarodowych, red. S. Burchill, Warszawa 2006, s. 208-214. 
zespół konwencji określających, co liczy się jako istotny wkład do dyskursu, co liczy się jako rozwiązanie zagadnienia, co liczy się jako dobry argument na rzecz danego rozwiązania, a co jako zarzut pod jego adresem. Dyskurs nienormalny powstaje wtedy, gdy do debaty przyłącza się ktoś nie znający obowiązujących w niej konwencji bądź też ktoś, kto ich nie respektuje. Owocem dyskursu normalnego jest [...] zespół twierdzeń, których prawdziwość mogą przyjąć wszyscy uczestnicy dyskursu uważani za »racjonalnych« przez innych jego uczestników. Owocem dyskursu nienormalnego zaś może być cokolwiek, od nonsensu począwszy, na rewolucji intelektualnej kończąc [...]"12. Epistemologia możliwa jest tylko wtedy, gdy istnieją ugruntowane i powszechnie akceptowane sposoby interpretowania rzeczywistości. Hermeneutyka natomiast pojawia się w efekcie zerwania z przekonaniem, że wypracowana dotychczas wiedza o świecie jest absolutnie słuszna. Nie może ona uchodzić za jakąś nową odmiany epistemologii, skoro powstaje właśnie poprzez jej odrzucenie - stanowi raczej swoistą jej metanarrację, szydzącą z epistemologicznej uniwersalistycznej pewności siebie.

Konstruktywistyczny sposób postrzegania rzeczywistości legł u podstaw postmodernizmu - obszernego i zróżnicowanego wewnętrznie nurtu, który w latach osiemdziesiątych XX w. przypuścił frontalny atak na prawomocność samych filarów (tak naukowych, jak i pozanaukowych) tożsamości nowożytnego Zachodu i całego świata industrialnego. Jean Baudrillard, Jacques Derrida, Jean-Francois Lyotard i im podobni postanowili przede wszystkim uzmysłowić ludziom u których znajdywali posłuch, że wszystkie elementy rzeczywistości społecznej można „stworzyć” na nowo poprzez ich alternatywne ,odczytanie”.

Czym jest postmodernizm? Odpowiadając w najogólniejszy sposób - metateorią, czy raczej metanarracją nowoczesności. Pomimo iż - jak zauważa Ryszard Nycz - pojęcie owo funkcjonuje obecnie w trojakim znaczeniu (odpowiednio w odniesieniu do: ponowożytnego okresu w dziejach zachodniej myśli; postindustrialnej fazy rozwojowej społeczeństw Zachodu oraz kompleksu nowych trendów w literaturze i sztuce) ${ }^{13}$, nietrudno zauważyć, że istota każdego z wymienionych wymiarów polega na krytycznym omówieniu pewnej specyfiki epoki industrialnej. Określenie „metateoria” niezbyt dobrze oddaje istotę rzeczy, jako że postmoderniści rzadko bywają „teoretyczni” w utartym (nowoczesnym) tego słowa znaczeniu: „mimo że uznają kluczową rolę ram teoretycznych w kształtowaniu przedmiotu badań, starają się nie wtłaczać na siłę konkretnych przypadków w abstrakcyjne pojęcia i logiki teoretyczne. [...] Warunkiem prowadzenia badań są wystarczająco »otwarte« i elastyczne ramy teoretyczne, które można »rozciagać« i reorganizować w trakcie analizy. Postawa taka wyklucza więc posługiwanie się esencjalistycznymi i redukcjonistycznymi teoriami społeczeństwa, określającymi wyniki badań niejako z góry" ${ }^{\prime 14}$, co koresponduje z podstawowym postulatem „metodologii” postmodernizmu, głoszącym konieczność odrzucenia pozytywistycznej Wielkiej Teorii - źródła rzekomo uniwersalnie prawdziwej wiedzy. Fakt ów naraża dokonania zwolenników omawianego nurtu na atak ze strony przedstawicieli bardziej tradycyjnych paradygmatów. Jacek Czaputowicz zaznacza, iż „krytycy oskar-

12 R. Rorty, Filozofia a zwierciadło natury, Warszawa 1994, s. 285.

13 Postmodernizm: antologia przekładów, red. R. Nycz, Kraków 1997, s. 9.

14 D. Howarth, Dyskurs, Warszawa 2008, s. 214. 
żają postmodernizm o koncentrację na negacji, relatywizm, nihilizm oraz podważenie całej tradycji Oświecenia poprzez dekonstrukcję logocentrycznych praktyk, systemów wiedzy i języka. Uzasadnione też wydają [...] się zarzuty, czynione na gruncie naukowym, że postmodernizm nie jest zdolny do dostarczenia »właściwej« wiedzy, nie zadaje bowiem pytań epistemologicznych i odmawia stosowania dowodów w celu rozstrzygania o prawdziwości twierdzeń" ${ }^{15}$. Osoby wysuwające podobne zastrzeżenia powinny jednak wpierw odpowiedzieć sobie na pytanie o to, czy zaproponowanie przez postmodernistycznych „wywrotowców” jakiejś alternatywnej recepty na Wielką Teorię nie stanowiłoby właśnie zaprzeczenia samej istoty postmodernizmu i czy nie byłoby to dla nich równoznaczne $\mathrm{z}$ popadnięciem na powrót $\mathrm{w}$ quasi-obiektywistyczny sposób myślenia, z którego tak usilnie starają się wyzwolić? Na aktualnym etapie swego rozwoju, postmodernizm nie potrzebuje własnej Wielkiej Teorii, jako iż jego sens polega właśnie na jej krytycznym odrzuceniu, tak, jak rortiańska hermeneutyka konstytuuje się poprzez konsekwentną negację epistemologii. Postmoderniści utrzymują, że systemy przekonań, które Zachód od czasów Oświecenia pojmował jako „ostateczną wiedzę”, „ostateczną filozofię” czy „ostateczną sztukę”, nie były w istocie niczym więcej, li tylko pewnymi typami opowieści o „wiedzy”, ,filozofii” i „sztuce”. Jeśli zatem opierają oni swą refleksję na przekonaniu, iż nie istnieje „wiedza prawdziwa” odsłaniająca „zbawienną prawdę," o świecie, dlaczego mielibyśmy oczekiwać od nich kompleksowych programów epistemologiczno-metodologicznych?

Studia kulturowe (ang. cultural studies) to dziedzina, czy raczej quasi-dziedzina zachodniej humanistyki, zrodzona na gruncie postmodernizmu ${ }^{17}$. Jej problematyczny charakter wynika z faktu, iż ,trudno jest w precyzyjny sposób wyznaczyć granice studiów kulturowych jako spójnej, jednolitej dyscypliny akademickiej o jednoznacznej tematyce, pojęciach i metodach, które odróżniająją od innych dyscyplin. Studia kulturowe są i zawsze były wielo- lub postdyscyplinarną dziedziną badawczą, nakładającą się w pewnym stopniu na inne dziedziny" ${ }^{\prime 18}$. Z drugiej strony, ,nie należy jednak sądzić,

15 J. Czaputowicz, Teorie stosunków międzynarodowych. Krytyka i systematyzacja, Warszawa 2007, s. 433.

${ }^{16}$ W opinii Richarda Rorty’ego, ,zbawienna prawda” to „potrzeba ulokowania wszystkiego - każdej rzeczy, osoby, zdarzenia, idei i poematu - w jednym kontekście, który będzie się jakoś odsłaniał jako naturalny, z góry dany i niepowtarzalny. Ma to być jedyny kontekst liczący się w kształtowaniu naszego życia, gdyż tylko w nim życie to pojawi się takim, jakie naprawdę jest”. R. Rorty, Filozofia jako polityka kulturalna, Warszawa 2009, s. 146. Od czasu platońskich „czystych idei” filozofia Zachodu zakładała, że na pytanie o „zbawienną prawdę” (będące jednocześnie pytaniem o sens życia) uda się w końcu udzielić ostatecznej odpowiedzi, podobnie, jak zachodni pozytywizm naukowy wierzył w możliwość ostatecznego odkrycia natury świata.

17 Trudno wskazać jakiś konkretny moment ukonstytuowania się studiów kulturowych jako odrębnej dziedziny naukowej, co wynika z faktu, iż 1) elastyczne granice ich pola zainteresowań nakazują niejako włączać do swego dorobku teoretycznego prace strukturalistów (F. de Saussure, R. Barthes), poststrukturalistów (J. Derrida, M. Foucault), przedstawicieli teorii krytycznej (T. Adorno, E. Fromm, J. Habermas, M. Horkheimer, J. Lacan), marksistów (L. Althusser, A. Gramsci) czy filozofów analitycznych (R. Rorty, L. Wittgenstein), które powstawały w różnym miejscu i czasie; 2) dyscyplina ta, uznając przedstawione w niniejszym artykule postulaty postmodernizmu, przejawiała (przynajmniej w początkach swego istnienia) niechęć i nieufność względem wszelkiego typu systematyzacji oraz instytucjonalizacji.

18 C. Barker, Studia kulturowe. Teoria i praktyka, Kraków 2005, s. 5. 
że studia kulturowe obejmują całość ludzkiego doświadczenia" ${ }^{19}$. Ich przedstawiciele (m.in. Paul Gilroy, Lawrence Grossberg, Stuart Hall), podzielając postmodernistyczne przekonanie o relatywnym charakterze świata społecznego, idą o krok dalej - nurtuje ich poszukiwanie ,związku pomiędzy zagadnieniami władzy i polityki kulturowej, czyli badanie sposobów przedstawienia marginalizowanych grup społecznych oraz reprezentacji »dla« nich przeznaczonych [...]. Wiedzy nie traktuje się tu jako zjawiska neutralnego czy obiektywnego, dostrzega się jej nieuchronną pozycyjność, czyli znaczenie pozycji, z której się mówi, tego, do kogo się mówi i jakie cele chce się osiagnąć" ${ }^{20}$. Innymi słowy - nie poprzestają oni na stwierdzeniu, że świat jest społecznie skonstruowany: próbują zrozumieć, dlaczego (w czyim interesie) jest on skonstruowany akurat tak, a nie inaczej? Wyraźnie polityczny, kontestacyjny i emancypacyjny wymiar analizy przybliża ich do przedstawicieli teorii krytycznej (z prac których czerpią z resztą pełnymi garściami), a jednocześnie - odróżnia od innych badaczy kultury: socjologów, antropologów czy historyków sztuki. Jak utrzymuje C. Barker, ,jednym z głównych założeń studiów kulturowych jest teza, że przedmiot ich dociekań [...] stanowi przestrzeń walki o znaczenie. Oznacza to, że pomiędzy różnymi sposobami postrzegania świata toczy się w obrębie kultury nieustanna walka o pierwszeństwo oraz pragmatyczne roszczenie do prawdy. Mówiąc szczegółowo, znaczenie i prawda są w kulturze ustanawiane w obrębie układów władzy. [...] Władza, rozumiana jako społeczna siła regulacyjna, która tworzy jednostkę, pozwala na zaistnienie określonych rodzajów wiedzy i wyklucza inne" 21 .

Strategia analityczna proponowana przez zwolenników omawianego podejścia koncentruje się na procesach, w których językowe „praktyki znaczące” określają sens rzeczywistości, narzucając pewne jej przedstawienia (reprezentacje) oraz wytwarzając jednostkowe i grupowe tożsamości, przez pryzmat których ludzie postrzegają siebie oraz innych. Należy uświadomić sobie, że „nie sposób traktować języka jako narzędzia służącego do przekazywania neutralnych politycznie informacji, skoro swe znaczenia czerpie on ze społecznych obszarów, w których operuje. Im bardziej pojmuje się go jako neutralny i naturalny, tym łatwiej będzie się stawał środkiem subtelnego ucisku wywieranego przez tych, którzy mają za sobą władzę i siłę" ${ }^{, 2}$. Jak zauważa R. Rorty, „niesprawiedliwość nie musi być postrzegana jako niesprawiedliwa nawet przez tych, którzy jej doświadczają, dopóki ktoś nie stworzy dla nich uprzednio nieodgrywanej roli. Dopiero wtedy, gdy ktoś ma wizję, głos, oraz głos, który potrafi tę wizję opisać, to, co wyglądało jako część natury, staje się kultura, to, co wyglądało jak los, staje się moralnym koszmarem. Do tego momentu jedynym dostępnym językiem jest język ciemiężyciela, a większość ciemiężycieli ma na tyle rozumu, by nauczyć ciemiężonych języka, w którym słowo »ciemiężony« brzmi dziwacznie [...] jeśli używa się go w odniesieniu do samego siebie"23.

19 Ibidem.

20 Ibidem.

21 Ibidem, s. 470-471.

22 E. Baldwin, B. Longhurst i in., Wstęp do kulturoznawstwa, op. cit., s. 91.

23 Cyt. za: C. Barker, op. cit., s. 502. 
Co więcej, ,znaczenia i reprezentacje kulturowe posiadają pewną materialność. Oznacza to, że są osadzone w dźwiękach, inskrypcjach, obiektach, obrazach, książkach, czasopismach i programach telewizyjnych. Tworzy się je, odgrywa, wykorzystuje i odczytuje w konkretnych kontekstach społecznych" ${ }^{\text {"24 }}$. Podobne zjawiska kulturowe składają się na względnie spójne, kompleksowe systemy znaczeń określane mianem formacji dyskursywnych, skrywające określone stosunki panowania. Zdaniem J. Czaputowicza, ,analogia między światem tekstowym i rzeczywistym polega na tym, że w obu z nich pewne struktury i znaczenia dominują, podczas gdy inne są marginalizowane. Postmodernistów interesuje to, jak określone wyobrażenia rzeczywistości cyrkulują, zdobywają hegemonię i przeważają oraz wytwarzają praktyczne polityczne efekty" ${ }^{\text {"25 }}$ Z $Z$ powyższych założeń wyłania się specyficzny trójkąt: znaczenie - tożsamość (podmiotowość) - władza, usytuowany w centrum ich krytycznych zainteresowań.

\section{„WLADZA OPISU” WEDLUG POSTSTRUKTURALISTÓW: TEKSTUALNOŚĆ I DYSKURS}

Pomimo, iż z punktu widzenia genezy zakreślonej w ten sposób wizji władzy nieocenioną rolę odegrali przedstawiciele materializmu historycznego, zwłaszcza Karol Marks (ideologia jako „fałszywa świadomość”), Antonio Gramsci (koncepcja hegemonii) i Steven Lukes (teoria trzech wymiarów władzy), istotniejsze zdają się być tutaj osiągnięcia reprezentantów poststrukturalistycznej teorii dyskursu ${ }^{26}$. Za jej założyciela uznaje się dość powszechnie Jacquesa Derridę ${ }^{27}$, w opinii którego dyskurs to tyle, co „,indeterministyczna quasi-struktura pisma albo tekstu” ${ }^{28}$ wytworzona historycznie w spontanicznej i przygodnej grze znaczeń i organizująca w danym miejscu oraz czasie (lub inaczej - w danej ,infrastrukturalnej” konfiguracji znaczeniowej) jednostkową percepcję rzeczywistości. Chociaż twierdzenie J. Derridy, w świetle którego „nie istnieje nic poza tekstem" brzmi kontrowersyjnie ${ }^{29}$, to jednak jest w nim sporo sensu. Jak bowiem zauważa C. Barker, ,,pojęcie tekstu obejmuje nie tylko słowa pisane, $[\ldots]$ lecz również wszystkie praktyki, które mają znaczenie. Dotyczy ono wytwarzania znaczeń przez obrazy, dźwięki, przedmioty (np. odzież) i czynności (np. taniec czy sport). Ponieważ obrazy, dźwięki, przedmioty i praktyki są systemami znaków, które funkcjo-

${ }^{24}$ C. Barker, op. cit., s. 8-9.

25 J. Czaputowicz, op. cit., s. 420.

26 Podstawowym elementem odróżniającym poglądy poststrukturalistów od klasycznego strukturalizmu Ferdinanda de Saussure'a, Rolanda Barthesa czy Claude'a Levi-Straussa, jest założenie, w świetle którego systemy znaczeń nie są trwałe i nigdy nie można zrekonstruować ich w sposób ostateczny. Wynika to $z$ faktu, iż w obrębie podobnych systemów znaczenia konstytuują się poprzez nieskończone odraczanie i odwoływanie się do innych znaczeń w permanentnie zmieniających się polach semantycznych (koncepcja ,różni” J. Derridy). Żaden dyskurs nie jest przeto nigdy strukturą doskonale zamkniętą i nie może zostać odczytany finalnie - samą jego istotę stanowi bowiem próba tymczasowego ustabilizowania swobodnego przepływu znaczeń w oparciu o fundamentalne dla niego ,punkty artykulacji”. C. Barker, op. cit., s. 107-108.

${ }_{27}$ Zob. więcej: J. Derrida, O gramatologii, Warszawa 1999.

28 D. Howarth, op. cit., s. 72.

${ }^{29}$ Ibidem, s. 76-79. 
nują w taki sam sposób jak język, możemy określić je jako teksty kulturowe"30. W innym zaś miejscu dodaje, iż „teksty opowiadają pewne historie, niezależnie od tego, czy jest to teoria względności Einsteina [...] czy ostatni odcinek Simpsonów. [...] Narracje to opowieści skonstruowane, które stanowią próbę wyjaśnienia sposobów funkcjonowania świata. Dostarczają nam struktur rozumienia i reguł odniesienia dotyczących sposobu konstrukcji świata społecznego, udzielając tym samym odpowiedzi na pytanie, jak mamy żyć" ${ }^{31}$. Jednocześnie każda z nich stanowi alternatywną interpretację rzeczywistości, odmienną perspektywę, wyprowadzoną z odmiennego punktu widzenia. „Perspektyw zatem nie można postrzegać jako prostych urządzeń optycznych służących do pojmowania »realnego świata«, jak teleskop czy mikroskop, ale także jako sam materiał tego »realnego świata«. [...] W rzeczywistości możemy powiedzieć, że nie ma obiektu lub wydarzenia na zewnątrz bądź uprzedniego w stosunku do perspektywy czy relacji” ${ }^{32}$, co wynika z faktu, iż ,zdarzenia osiagają status »realnych « nie dlatego, że się wydarzyły, ale dlatego, że są zapamiętane i ponieważ zajęły miejsce w narracji ${ }^{\prime 3}$. Innymi słowy - świat jest tekstem (narracja), gdyż jest wytwarzany i funkcjonuje w jednostkowej świadomości jako tekst: ludzkiemu doświadczeniu dostępne są nie tyle obiektywne byty (które mogłyby składać się na jakąs obiektywną rzeczywistość), co ich subiektywne opisy.

Skoro zatem świat jest tekstem, jego badanie nie może odbywać się inaczej, niż poprzez odczytanie tekstu, czyli - metodą hermeneutyczną ${ }^{34}$. Derrida proponuje w tym miejscu strategię dekonstrukcji, zorganizowaną wokół przekonania, iż specyficzna dla industrialnego Zachodu narracja opisująca rzeczywistość opiera się na opozycjach binarnych, będących w swej istocie kolejnymi egzemplifikacjami dychotomii ,wewnątrz - zewnątrz". W takich przeciwstawnych zestawieniach (np. rzeczywistość - pozór, mężczyzna - kobieta, rozum - szaleństwo, suwerenność - anarchia) element „wewnętrzny" (odpowiednio: rzeczywistość, mężczyzna, rozum, suwerenność) zawsze jest w mniej lub bardziej czytelny sposób uprzywilejowany względem „zewnętrznego”. Praktyka dekonstrukcji polega na: 1) odtworzeniu takich binarnych układów organizujących percepcję rzeczywistości (chociażby w celu ukazania, iż są one nad wyraz ograniczające, wykluczając ze swego spektrum całą gamę możliwości pośrednich); 2) dowiedzeniu niepoprawności wartościowania jednego członu kosztem drugiego (jako że są one sobie wzajemnie równie potrzebne: „zewnętrze” zostaje zdefiniowane przez pryzmat „wnętrza”, ale „wnętrze” tak samo może dookreślić swoją istotę wyłącznie w relacji do „zewnętrznej” antytezy) oraz 3) wypracowaniu alternatywnego (tzn. niebinarnego) ujęcia problemu.

Derridiańską koncepcję tekstualności świata reinterpretacji poddał Michel Foucault - zapewne najbardziej znany i wpływowy przedstawiciel teorii dyskursu. Dokonawszy wpierw gruntownej i ahistorycznej analizy strukturalnej poszczególnych formacji dys-

C. Barker, op. cit., s. 11.

Ibidem, s. 32.

R. Devetak, Postmodernizm, w: Teorie stosunków międzynarodowych, op. cit., s. 239.

Ibidem.

34 W swym pierwotnym znaczeniu, wywodzące się ze starożytnej Grecji pojęcie hermeneutyki, odnosiło się właśnie do sztuki objaśniania i interpretacji tekstów. 
kursywnych w ramach okresu ,archeologicznego" swych badań (obejmującego prace takie, jak Stowa i rzeczy $y^{35}$ czy Archeologia wiedzy ${ }^{36}$ ), autor przechodzi do rozważań genealogicznych (zauważalnie inspirowanych filozofią Friedricha Nietzschego), w których ,pojęcie dyskursu nadal znajduje szerokie zastosowanie, chociaż dyskursy są już traktowane nie jako autonomiczne systemy wypowiedzi naukowych, lecz jako wytwory połączonych stosunków władzy i wiedzy"37. Generowanie wiedzy traktowane jest tutaj jako kwestia nie tyle poznawcza, ile polityczna. Sam M. Foucault utrzymuje, że „władza i wiedza wprost się ze sobą wiążą; że nie ma relacji władzy bez skorelowanego z nimi pola wiedzy, ani też wiedzy, która nie zakłada i nie tworzy relacji władzy" ${ }^{38}$. Tak więc ,genealogia jest sposobem historycznego myślenia, który odsłania i wskazuje na znaczenie relacji władza-wiedza" ${ }^{39}$. Podczas, gdy archeologia to czysty opis struktury dyskursu oraz sposobu funkcjonowania składających się na nią reguł formacyjnych, genealogia interesuje się przede wszystkim „rolą jaką władza i dominacja odgrywają w konstytuowaniu dyskursów, tożsamości i instytucji ${ }^{40}$. Historia jawi się tutaj jako rozgrywająca się w czasie, nieciagła rywalizacja alternatywnych formacji dyskursywnych, współzawodniczących o status ,prawdziwego” opisu świata. Są one powiązane zarówno z adekwatnymi mechanizmami dyscyplinującymi (np. szpitale, więzienia, zakłady psychiatryczne), jak i z określonymi identyfikacjami jednostkowymi i grupowymi (przejawiającymi się np. w specyficznym postrzeganiu „zdrowia” czy „seksualności”). Pojęcia, tożsamości, przedmioty materialne oraz praktyki społeczne ześrodkowują się pod postacią „urządzenia” (aparatus lub dispositif), które jest dla M. Foucaulta „heterogenicznym zespołem składającym się z dyskursów, instytucji, form architektonicznych, regulacji, praw, reform administracyjnych, wypowiedzi naukowych, sądów filozoficznych, moralnych i filantropijnych - krótko mówiąc, zarówno z tego, co wypowiedziane w języku, jak i z tego, co w języku niewypowiedziane"41. Rozliczne „urządzenia” kształtują z kolei właściwy danej epoce „sposób życia”. W przedstawianej perspektywie, rozwijanej później m.in. przez Ernesta Laclaua i Chantal Mouffe ${ }^{42}$, „pojęcie dyskursu odnosi się zarówno do języka, jak i do praktyk i oznacza uporządkowaną formę wiedzy wytworzoną poprzez język, dzięki której obiekty materialne i praktyki społeczne zyskują znaczenie. Dyskurs konstruuje, definiuje i wytwarza przedmioty wiedzy, które stają się w ten sposób zrozumiałe, a jednocześnie wyklucza inne sposoby pojmowania jako niezrozumiałe"43. Klasyczna dychotomia ontologiczna: idea (język) - materia (przedmiot, działanie) ulega tedy zatarciu, co nie może dziwić, zważywszy na fakt, iż - jak podkreśla C. Barker - ,język nie

35 M. Foucault, Słowa i rzeczy: archeologia nauk humanistycznych, Gdańsk 2006.

M. Foucault, Archeologia wiedzy, Warszawa 2002.

D. Howarth, op. cit., s. 109.

8 M. Foucault, Nadzorować i karać. Narodziny więzienia, Warszawa 1993, s. 34.

39 R. Devetak, Postmodernizm, w: Teorie stosunków międzynarodowych, op. cit., s. 235.

40 D. Howarth, op. cit., s. 116.

41 Cyt. za: D. Howarth, op. cit., s. 125. Omówienie na przykładzie „urządzenia związku” oraz „urządzenia seksualności”, zob.: M. Foucault, Historia seksualności, Warszawa 1995, s. 95-102.

${ }^{42}$ Zob.: E. Laclau, C. Mouffe, Hegemonia i socjalistyczna strategia. Przyczynek do projektu radykalnej polityki demokratycznej, Wrocław 2007.

${ }^{43}$ C. Barker, op. cit., s. 20-21. 
jest neutralnym medium formułowania i przekazywania wartości, znaczeń i form wiedzy, które istnieją niezależnie, poza jego granicami - stanowi on raczej ich czynnik sprawczy"44. Jeśli, przykładowo, wyrażona w nim wiedza nakazuje definiować pewne grupy społeczne (płciowe, etniczne itp.) jako „gorsze” (np. „mniej uzdolnione”, „,niebezpieczne”, „niesamodzielne”), to podobne założenia przekładają się finalnie na określone typy rzeczywistych działań względem takich podmiotów. W ten sposób dominacja początkowo jedynie wyobrażona lub zwerbalizowana staje się faktem społecznym. Skoro zaś konfiguracje znaczeniowe przejawiają realną zdolność modelowania świata ludzi i przedmiotów, to definicja dyskursu musi zostać poszerzona o relacje wiążące słowniki z historycznymi systemami społecznych instytucji i praktyk ${ }^{45}$.

Jak zauważa J. Czaputowicz, „dyskurs jest [...] systemem władzy, dotyczy bowiem narzucania innym określonej definicji prawdy i fałszu. Władza zawsze prezentuje się jako posiadaczka prawdy" ${ }^{\text {"46 }}$, ta z kolei (przynajmniej zdaniem obiektywistów) uchodzi za domenę wiedzy. Jedną z bardziej czytelnych analiz powstania i wzajemnego warunkowania się kompleksu władzy-wiedzy odnaleźć możemy na kartach Historii szaleństwa $w$ dobie klasycyzmu ${ }^{47}$. M. Foucault pokazuje tutaj, w jaki sposób powstanie w XVIII w. kapitalistycznego społeczeństwa burżuazyjnego, funkcjonującego podług odmiennej, niż dotychczasowa (feudalna) logiki ekonomicznej, skutkowało artykulacją dyskursu „obłędu”, pozwalającego eliminować z przestrzeni publicznej ludzi w świetle owej logiki zbędnych, gdyż nieproduktywnych (nędzarzy, przestępców, chorych psychicznie itp.). Dyskurs „szaleństwa” służył uprawomocnieniu nowego porządku, co z kolei następowało drogą produkcji wiedzy naukowej w sferze szeroko pojętej psychiatrii. Wiedza wytwarza problem zgodny z interesem władzy, władza zaś zapewnia wytwórcom wiedzy możliwości działania oraz korzyści płynące z rozwiązania tegoż problemu - zachodzi tutaj oczywista relacja wzajemnej współzależności. Nie istnieje coś takiego, jak „,bezinteresowna prawda” - summa summarum prawda okazuje się współtwórcą i sojusznikiem dominacji. „Wiedza jest tu zatem formą władzy, wpisaną w proces wytwarzania podmiotowości”, ${ }^{4}$ - stąd zaś płynie konstatacja, iż „każda wiedza jest - mniej lub bardziej pośrednio - ideologią"49.

Dookreślenie najważniejszych stanowisk i kategorii pojęciowych w obrębie cultural studies stanowi punkt wyjścia dla ukazania, w jaki sposób mogą one zostać wykorzystane dla rozszerzenia perspektyw poznawczych nauki o stosunkach międzynarodowych. Wykorzystana zostanie w tym celu analiza dyskursu orientalistycznego, dokonana przez Edwarda Saida ${ }^{50}$.

\footnotetext{
44 Ibidem, s. 100.

45 Przykładowo, dyskurs thatcheryzmu obejmował nie tylko idee (wolność, monetaryzm, prawo i porządek), ale też praktyki (przedsiębiorczość, silne przywództwo) oraz reformy instytucjonalne państwa. D. Howarth, op. cit., s. 160.

46 J. Czaputowicz, op. cit., s. 421.

47 M. Foucault, Historii szaleństwa w dobie klasycyzmu, Warszawa 1987.

48 C. Barker, op. cit., s. 266.

49 A. Zybertowicz, op. cit., s. 183.

50 E. Said, Orientalizm, Poznań 2005.
} 


\section{STUDIA KULTUROWE W ANALIZIE STOSUNKÓW MIĘDZYNARODOWYCH: CASUS ORIENTALIZMU}

Orientalizm, wpływowa praca poststrukturalistyczna z końca lat siedemdziesiątych $\mathrm{XX}$ wieku, proponuje nową, niekonwencjonalną interpretację zarówno historycznych, jak i współczesnych przejawów zależności kolonialnej, w sposób istotny wzbogacając i odświeżając debatę na ten temat. Pod tytułowym pojęciem rozumie autor powstający przez stulecia na Zachodzie (wpierw w Europie, potem również w Stanach Zjednoczonych) złożony i zróżnicowany wewnętrznie dyskurs strukturyzujący określony sposób myślenia o oriencie (Azji), a ponadto - implikujący pochodne posunięcia i praktyki względem tak regionu, jak jego mieszkańców. Zdaniem E. Saida: „mówienie o orientalizmie to mówienie przede wszystkim, choć nie wyłącznie, o brytyjskim i francuskim przedsięwzięciu kulturowym, projekcie, którego zakres obejmuje tak odmienne elementy, jak Indie i Lewant, teksty i krainy biblijne, handel przyprawami, armie kolonialne i długa tradycja kolonialnej administracji, wspaniały zbiór dzieł naukowych, niezliczonych »ekspertów« i »wyrobników« orientalizmu, jego profesorów, złożony szereg »orientalnych « idei (takich jak orientalny despotyzm, przepych, okrucieństwo czy zmysłowość), liczne na Wschodzie sekty, filozofie i mądrości udomowione na lokalne europejskie potrzeby - listę tę można ciagnąć prawie w nieskończoność" ${ }^{51}$. Jednocześnie pojmować go należy ,jako zbiór instytucji zajmujących się Orientem, czyli wypowiadających się na jego temat, wyrażających autorytatywne poglądy, opisujących go, nauczających o nim, zasiedlających go i rządzących nim. Krótko mówiąc, orientalizm to zachodni sposób dominowania, restrukturyzowania i posiadania władzy nad Orientem”" ${ }^{2}$, dzięki któremu „kultura europejska potrafiła ujarzmić, a nawet stworzyć Orient politycznie, socjologicznie, wojskowo, ideologicznie, naukowo i kreacyjnie" ${ }^{\text {"53 }}$. Można powiedzieć, że „W pewnym sensie był on biblioteka, czy raczej [...] archiwum informacji powiązanym w całość za pomocą rodziny idei i jednoczącego je zestawu wartości, które [...] wyjaśniały zachowania ludzi Orientu; przypisywały im mentalność, genealogię i atmosferę; a co najważniejsze, pozwalały Europejczykom rządzić nimi i nawet uznawać ich za fenomen o określonych cechach [...]"54.

Dyskurs orientalistyczny w całej swej zawiłej złożoności bazował na właściwej industrialnemu Zachodowi prostej opozycji binarnej: Europa-Orient, przy czym, w myśl intuicji J. Derridy, pierwszy z jej członów (,wewnątrz”) cieszył się założonym apriorycznie (choć nie zawsze uświadomionym) uprzywilejowaniem. Jak zauważa E. Said: „wielu pisarzy - wśród których znajdowali się nie tylko poeci, powieściopisarze i filozofowie, ale również teoretycy polityczni, ekonomiści oraz urzędnicy imperialni - przyjęło to podstawowe rozróżnienie [...] za punkt wyjścia rozwijanych teorii, eposów, powieści, studiów społecznych i relacji politycznych dotyczących Orientu, jego mieszkańców, zwyczajów, »umysłowości«, przeznaczenia i tak dalej. Taki orientalizm obejmuje zarówno Ajschylosa, jak i Victora Hugo, zarówno Dantego, jak i Karola

51 Ibidem, s. 32-33.

52 Ibidem, s. 31.

53 Ibidem, s. 32

54 Ibidem, s. 80. 
Marksa" ${ }^{55}$. Podobnie, jak w przypadku innych tego typu opozycji, przeciwieństwa pozostają względem siebie funkcjonalnie zależne i wzajemnie się wspierają: Europejczycy stworzyli Orient jako swą własną narrację o Wschodzie, lecz w równym stopniu „dzięki Orientowi została zdefiniowana Europa (czy dokładniej Zachód) jako przeciwwaga jego wizerunku, idei, osobowości i doświadczenia" ${ }^{56}$. Jednocześnie, ze względu na uprzywilejowanie jednej z tych kategorii względem drugiej (odpowiadające technologicznej i militarnej przewadze europejskich imperiów kolonialnych nad mieszkańcami Azji), treści dyskursu orientalistycznego ,są zawsze symetryczne w stosunku do europejskiego odpowiednika, a równocześnie od niego gorsze, co czasami jest sprecyzowane, a czasami nie" ${ }^{97}$. Fakt ów wynika przede wszystkim ze skłonności orientalistów do przyjmowania w swych analizach perspektywy porównawczej, w ramach której poszczególne rozwiązania kulturowe (językowe, religijne, obyczajowe itp.) społeczeństw Wschodu postrzegane były jako niedoskonałe „odpowiedniki” doskonałych wzorców zachodnich. Nic więc dziwnego, że w pismach oraz wystąpieniach Brytyjczyków pokroju Arthura Jamesa Balfoura czy lorda Cromera, „ludzie Orientu i Arabowie są ukazywani jako ludzie łatwowierni, »pozbawieni energii i inicjatywy«, oddani »wylewnym pochlebstwom «, intrygom, knowaniom, a także są okrutni dla zwierząt; [...] są niepoprawnymi kłamcami, są »ospali i podejrzliwi«, we wszystkim różni od prostej, bezpośredniej i szlachetnej rasy anglosaskiej”"58. Konstytutywnym wyznacznikiem wschodniej mentalności staje się tedy „niechlujność” rozumowania, wynikająca z niezdolności do racjonalnego myślenia, które przecież, zdaniem wielu XIX-wiecznych teoretyków (zwłaszcza Maxa Webera), wyznaczało wyjątkową specyfikę zachodniej nowoczesności. Analogicznie, islam interpretowano przez wieki jako ariańską herezję (czyli coś w rodzaju niedoskonałej wersji chrześcijaństwa), Mahometa - jako niedoskonały „odpowiednik” Chrystusa itd. „W ramach dziedziny porównawczej, jaką stał się orientalizm [...], Orient sam w sobie jest intelektualnie podległy Zachodowi. Jako materiał badań lub przemyśleń uzyskał wszystkie cechy nieodłączne słabości. Stał się przedmiotem kaprysów najróżniejszych teorii, które wykorzystywały go jako ilustrację swych tez" ${ }^{29}$. Jednocześnie działania wielu orientalistów nacechowane były zaangażowaniem normatywnym: dostrzegając ,ułomność” Wschodu względem „,idealnego" Zachodu, dążyli oni - w pojmowanej na swój sposób dobrej wierze - do „ulepszenia” tego niedoskonałego, obcego świata poprzez jak najwierniejsze upodobnienie go do Europy, nawet jeśli działania takie miałyby wywołać początkowy sprzeciw „prymitywnych” i ,irracjonalnych” tubylców.

W celu uporządkowania i usystematyzowania powyższych rozważań, powinniśmy teraz rozpatrzyć trzy pozornie odmienne, lecz $\mathrm{w}$ istocie wzajemnie wspierające się i uzupełniające wymiary orientalizmu. Najstarszy z nich odnosi się do kompleksu zawartych w legendach, bajkach, poematach, sztukach teatralnych, pieśniach oraz relacjach znanych podróżników, zobiektywizowanych przedstawień składających się na

\footnotetext{
55 Ibidem, s. 31.

56 Ibidem, s. 30.

57 Ibidem, s. 19.

58 Ibidem, s. 76

59 Ibidem, s. 223.
} 
wiedzę potoczną o społeczeństwach Azji. Orientalizm oznacza tutaj „pewien zbiór fantazji, wyobrażeń i słownictwa dostępny dla każdego, kto próbował się wypowiadać na temat obszarów leżących na wschód od linii podziału"60. Podstawy takiego „zdroworozsądkowego” orientalizmu odnajdujemy już w pismach Herodota oraz „Persach” Ajschylosa i „Bachantkach” Eurypidesa. Pierwszy wśród wymienionych dramaturgów wytycza linię podziału pomiędzy zwycięską Europą i pokonaną Azją pogrążoną w poczuciu klęski po nieudanej wyprawie wojennej przeciwko Hellenom. „Ajschylos reprezentuje Azję, każe jej mówić poprzez osobę starej perskiej królowej, matki Kserksesa. To Europa wyraża Orient; to wyrażenie tyczy się nie lalkarza poruszającego marionetkami, ale prawdziwego stwórcy, którego dająca życie moc wyraża, ożywia i wyznacza przestrzeń poza znajomymi granicami, przestrzeń, która w przeciwnym razie pozostalaby milcząca i niebezpieczna”61. W „Bachantkach”, w których grecka „racjonalność podkopywana jest przez wschodnie ekscesy, te tajemnicze, pociagające przeciwieństwa wartości uznawanych przez nas za normalne" ${ }^{\$, 2}$, na zakreśloną uprzednio przez Ajschylosa granicę nakłada się kolejna opozycja: europejskie opanowanie kontra azjatycka emocjonalna zmysłowość. W późniejszym okresie skłonność do podkreślenia odmienności Zachodu i Wschodu znalazła swe odzwierciedlenie w taksonomicznych opisach rzymskich geografów i historyków, średniowiecznych „pieśniach o czynie” (zwłaszcza tych poświęconych bohaterom rekonkwisty), bajkach Mandeville'a, relacjach Marco Polo oraz opowieściach pielgrzymów i krzyżowców. Orientalizm „zdroworozsądkowy" przeżywał swój rozkwit w epoce romantyzmu, kiedy to pisarze i poeci pokroju Gustava Flauberta, Wolfgang Goethego czy Victor Hugo spopularyzowali wizerunek Wschodu jako ośrodka fascynujących miejsc, legendarnych postaci i niezwykłych wydarzeń. Również obecnie ,poglądy orientalistów zalewają prasę i generują potoczne sposoby myślenia. Arabów na przykład potocznie uważa się za jeżdżących na wielbłąach terrorystów o haczykowatych nosach, a także za sprzedajnych lubieżników, których niezasłużone bogactwo stanowi afront dla prawdziwej cywilizacji. Zawsze gdzieś czai się założenie, że chociaż zachodni konsument liczebnie stanowi na świecie mniejszość, jednak ma prawo posiadać lub eksploatować (albo i jedno, i drugie) większość bogactw naturalnych świata. Dlaczego? Ponieważ w przeciwieństwie do ludzi Orientu jest on prawdziwym człowiekiem" ${ }^{63}$.

Drugi spośród trzech omawianych wymiarów odnosi się do orientalizmu jako dyscypliny akademickiej „produkującej” na użytek Zachodu wiedzę naukową o oriencie. Ta perspektywa jest chronologicznie późniejsza - za jej symboliczny początek uznać można rok 1312, kiedy to na soborze w Vienne zapadła decyzja o utworzeniu katedr: arabskiej, greckiej, hebrajskiej i syryjskiej na uniwersytetach w Paryżu, Oksfordzie, Bolonii, Awinionie i Salamance ${ }^{64}$. Pomimo, iż nie powinno się zapominać o przedsięwzięciach badawczych podejmowanych w okresach wcześniejszych (takich, jak wyprawa Williama Jonesa do Indii w XVIII w.), szczytowy moment rozwoju nowoczes-

$\begin{array}{ll}60 & \text { Ibidem, s. } 121 . \\ 61 & \text { Ibidem, s. } 100 . \\ 62 & \text { Ibidem. } \\ 63 & \text { Ibidem, s. } 166 . \\ 64 & \text { Ibidem, s. } 90 .\end{array}$ 
nego orientalizmu ,naukowego" przypadł na wiek XIX, naznaczony zarówno wieloma osiagnięciami indywidualnymi (badania nad językami semickimi Ernesta Renana i Silvestre'a de Sacy, An Account of the Manners and Customs of the Modern Egyptians Williama Lane'a itp.), jak i dynamiczną instytucjonalizacją samej dyscypliny (powstające lawinowo struktury akademickie, wydawnictwa czy stowarzyszenia takie, jak Royal Asiatic Society). „Zachód w dziewiętnastym i dwudziestym wieku przyjął założenie, iż Orient i wszystko, co się na niego składa, jest, jeśli nie ewidentnie gorsze, to przynajmniej wymaga korekty i badań ze strony Zachodu. Orient oglądano z perspektywy szkolnej klasy, sądu, więzienia czy ilustrowanego podręcznika, orientalizm zatem był wiedzą o Oriencie umieszczającą elementy orientalne w klasie, sądzie, więzieniu czy podręczniku, aby je zbadać, przestudiować, ocenić, zdyscyplinować lub nimi rządzić" 65 .

Dwóm zarysowanym powyżej perspektywom, mimo iż znacząco od siebie odmiennym, przyświecał w istocie ten sam cel - racjonalizacja odległego i niezrozumiałego dla Europejczyków orientu przez ,przełożenie” go na język Zachodu, ,przefiltrowanie” przez wymogi zachodniej „opowieści” o świecie. Jak zauważa E. Said, podobne skłonności nie są same w sobie niczym niezwykłym, gdyż „wszystkie kultury narzucają surowej rzeczywistości poprawki, zmieniając ją z pewnych nieokreślonych obiektów w elementy systematycznej wiedzy [...]; wszystkie kultury miały tendencję do całkowitego przekształcania innych kultur, odbierając je nie takimi, jakie są, ale takimi, jakie z korzyścią dla odbiorcy być powinny" ${ }^{\text {"66 }}$. Historyczna wyjątkowość zachodniego orientalizmu wynikała raczej z globalnej skali samego przedsięwzięcia. Odmienność i oddalenie przestrzenne Azji od stuleci rodziły w Europejczykach potrzebę zapełnienia luk poznawczych jakąś hybrydalną formą quasi-wiedzy, na wpół rzetelnej, na wpół-wyobrażonej, która jednak posiadała jedną podstawową cechę: pozwalała „ustrukturyzować" kontakt z orientem w sposób dla nich zrozumiały i bezpieczny, „oswoić" Wschód poprzez nałożenie nań zachodniej siatki wartości, pojęć i przekonań, czyniąc go finalnie odległym echem lub dziwaczną odmianą znajomego, zachodniego świata. Zdaniem E. Saida, orientalizm stara się osiągnąć „równocześnie dwie rzeczy: charakteryzowanie Orientu jako czegoś obcego oraz schematyczne włączanie go w teatralną scenę, której widownia, kierownik i aktorzy stoją po stronie Europy i tylko Europy. Stąd wahanie się pomiędzy znajomym i obcym; Mahomet jest zawsze oszustem (znanym, ponieważ stara się być taki jak Jezus, którego znamy) i zawsze człowiekiem Wschodu (obcym, ponieważ choć pod pewnymi względami jest »taki, jak« Jezus, ostatecznie wcale taki nie jest) ${ }^{, 67}$. Tak oto „orientalista zawsze sprawia, że jego praca zmienia Orient w coś zupełnie innego: czyni to dla siebie, dla swojej kultury, a w niektórych przypadkach, jak sam uważa, dla samego Orientu. Ten proces przemiany jest procesem zdyscyplinowanym: jest wykładany na uczelniach, ma własne zrzeszenia, czasopisma, słownictwo, retorykę - a wszystko to jest w podstawowy sposób połączone z dominującymi kulturalnie i politycznie normami Zachodu i przez nie dostarczane"68.

$\begin{array}{ll}65 & \text { Ibidem, s. } 79 . \\ 66 & \text { Ibidem, s. } 114 . \\ 67 & \text { Ibidem, s. } 119 . \\ 68 & \text { Ibidem, s. } 114 .\end{array}$ 
Mówiąc krótko, w obrębie omawianego dyskursu „Orient nie jest po prostu Orientem, ale Orientem, który został zorientalizowany”, ${ }^{, 9}$. Sęk w tym, że „po pewnym czasie czytelnik zapomina o wkładzie pracy ze strony orientalisty i uznaje rekonstrukcję Orientu [...] za Orient tout court. Obiektywna struktura (określenie Orientu) i subiektywna restruktura (reprezentacja Orientu dokonana przez orientalistę) stają się wymienne. Orient zostaje pokryty warstwą racjonalności orientalisty: zasady orientalisty stają się zasadami Orientu. Wschód przestaje być odległy - staje się dostępny; przestaje być groźny - staje się pedagogicznie użyteczny; przestaje być zagubiony - zostaje odnaleziony, nawet jeżeli niektóre brakujące części ulegają w tym procesie bezpowrotnemu zniszczeniu" ${ }^{\prime 70}$

Dochodzimy w tym miejscu do trzeciej perspektywy pojmowania analizowanego terminu, a mianowicie - do orientalizmu jako instrumentu zachodniego panowania nad Orientem. Jak zauważa E. Said, „,stosunki pomiędzy Zachodem a Wschodem to stosunki siły, dominacji, złożonej hegemonii o różnym nasileniu [...]. Orient został zorientalizowany $[\ldots]$ ponieważ mógł zostać zorientalizowany" "71, ponieważ jego mieszkańcy po prostu nie byli w stanie przeciwstawić się europejskiej obecności w regionie oraz europejskim sposobom myślenia o nim. Ponieważ Orient okazał się niezdolny do samodzielnego „mówienia” o sobie, europejscy naukowcy, podróżnicy i poeci mogli „mówić” o nim i w jego imieniu. To przez ich usta (czy raczej teksty), ,przemawiał” do (zachodniego) świata Wschód, lecz w istocie był to nie tyle Wschód jako taki, ile prywatne wyobrażenia autorów o Wschodzie, w mniej lub bardziej uświadomiony sposób przefiltrowane już uprzednio zarówno przez wiekową tradycję dyskursu orientalistycznego, jak i swoiste subiektywne „zniekształcenia” implikowane przez ich „,imperialne” tożsamości. Stojąc na gruncie konstruktywistycznego modelu poznania, E. Said wyklucza możliwość istnienia czegoś takiego, jak wiedza apolityczna. Jeśli bowiem „nikt nie obmyślił jeszcze sposobu na odseparowanie uczonego od jego związków z życiem codziennym, od - uświadomionych lub nie - wpływów i poglądów klasy, do której należy, od pozycji społecznej czy działań wynikających po prostu z faktu bycia członkiem społeczeństwa" ${ }^{12}$, wiedza akademicka o Wschodzie już w samym punkcie wyjścia „skażona” być musiała jego podległym, kolonialnym statusem. Uwaga ta odnosi się zresztą w równym stopniu do wszystkich innych osób „,wypowiadających" się na analizowany temat, m.in. artystów. Jak przytomnie zauważa autor, „,prawie każdy dziewiętnastowieczny pisarz (a sprawdza się to również w stosunku do prawie wszystkich pisarzy wcześniejszych) był zaskakująco świadomy istnienia imperium: [...] John Stuart Mill, Arnold Carlyle, Newman, Macaulay, Ruskin, George Eliot, a nawet Dickens mieli bardzo jasno określone poglądy na temat rasy i imperializmu, a wpływ tych poglądów można łatwo zauważyć w ich dziełach" "73. Państwa imperialne lub quasi-imperialne (Wielka Brytania i Francja w XIX wieku, USA współcześnie), kształtują bowiem tożsamość swych obywateli w taki sposób, aby myśleli oni o sobie oraz o świecie

\footnotetext{
69 Ibidem, s. 160.

70 Ibidem, s. 192.

71 Ibidem, s. 35.

72 Ibidem, s. 40-41.

73 Ibidem, s. 46.
} 
zewnętrznym przez pryzmat silnej identyfikacji personalnej z przeważającą w systemie międzynarodowym potęgą. Stąd też „orientalizm dość konsekwentnie opiera się na łatwej do zaadaptowania pozycyjnej wyższości ludzi Zachodu, wikłającej ich w rozliczne relacje z Orientem” "74. I chociaż „nie jest tak, że orientalizm sztywno określa, co można, a czego nie można powiedzieć o Oriencie, istnieje jednak cała sieć powiązanych ze sobą wpływów i interesów, które dochodzą do głosu [...] zawsze wtedy, kiedy mowa jest o tym zadziwiającym tworze [... $]^{375}$.

Punktem zwrotnym, przekształcającym orientalizm w narzędzie europejskiego kolonializmu, była zdaniem E. Saida inwazja sił francuskich na Egipt (1798 r.), „która na wiele sposobów stanowi przykład prawdziwie naukowego przywłaszczenia sobie jednej kultury przez drugą, wyraźnie silniejszą" ${ }^{96}$. Nowatorstwo militarnej operacji $\mathrm{N}$. Bonapartego wynikało z ogromnego nacisku położonego na przyswojenie (w fazie przygotowawczej) oraz wytwarzania (w fazie realizacji) orientalistycznej wiedzy o obiekcie okupacji. Władza i wiedza od samego początku szły tutaj ze sobą w parze: wiedza wytwarzała władzę, a władza - wiedzę. Napoleon, podobnie jak późniejsi, brytyjscy okupanci - A. J. Balfour i Cromer - „uważał podbój Egiptu za przedsięwzięcie wykonalne, ponieważ znał ten kraj w sensie taktycznym, strategicznym i - czego nie należy nie doceniać - tekstualnym, czyli jako coś, o czym można przeczytać i co można poznać dzięki pismom współczesnych i klasycznych europejskich autorytetów. [...] Napoleońskie plany podboju Egiptu stały się pierwszym z długiej listy zetknięć z Orientem, przy okazji których szczególna wiedza orientalisty była używana w funkcji kolonialnej $[\ldots]^{, " 77}$. Bonaparte dostrzegał, iż zrozumienie specyfiki Egiptu stanowi klucz do jego opanowania: kto bowiem posiada wiedzę o ludziach Wschodu, ten wie, jak z nimi postępować, jak ich do siebie przekonać, jak reagować na ich zachowania itp. Gromadząca fakty i przetwarzająca je w systematyczną wiedzę (lingwistyczną, etnograficzna, geograficzną itd.) armia orientalistów, którą ze sobą zabrał, a której wysiłki zaowocowały monumentalnym Description de l'Egypte, miała zapewnić Europejczykom ,utrzymanie kursu” na wodach tego obcego bezkresu, jakim był Orient. Jednocześnie wiedza owa kreowała uzasadnienie dla francuskiej okupacji regionu, postrzeganego potocznie jako jedna z kolebek europejskiej cywilizacji. „Ponieważ Egipt był pełen znaczeń dla sztuki, nauki i rządu, stanowił scenę, na której rozegrają się wydarzenia historyczne o znaczeniu światowym. Zajmując Egipt, nowoczesna potęga prezentuje swą siłę i usprawiedliwia historię: własny los Egiptu stanowił jedynie dodatek do działania takiej potęgi, wywodzącej się z Europy. Ona również przechodzi do historii: jej element wspólny określają najlepiej postaci takiego formatu, jak Homer, Aleksander, Cezar, Platon, Solon i Pitagoras, którzy niegdyś zaszczycili Orient swą obecnością. Krótko mówiąc, Orient istniał jako zbiór wartości połączonych nie z jego współczesną rzeczywistością, ale z kontaktami, jakie miał z europejską przeszłością, ${ }^{\text {78 }}$.

\footnotetext{
74 Ibidem, s. 37.

75 Ibidem, s. 32.

76 Ibidem, s. 81.

77 Ibidem, s. 130

78 Ibidem, s. 135.
} 
Wiedza wypracowana przez napoleońskich orientalistów stała się kanwą dla podobnych przedsięwzięć, zwłaszcza zapoczątkowanej w 1882 r. brytyjskiej obecności w tym państwie. Współzależność władzy-wiedzy uwidaczniają wnioski płynące z przemówienia wygłoszonego przez Arthura Jamesa Balfoura w Izbie Gmin w 1910 r.: „Anglia zna Egipt; Egipt jest tym, co zna Anglia; Anglia wie, że Egipt nie może posiadać samorządu; Anglia potwierdza to, okupując Egipt; dla Egipcjan Egipt jest tym, co Anglia okupuje i czym obecnie rządzi; zatem obca okupacja staje się "podstawą" współczesnej cywilizacji egipskiej; Egipt wymaga, a właściwie domaga się brytyjskiej okupacji”" " . Zdaniem A. J. Balfoura, Brytyjczycy są w stanie „podźwignąć” tę niegdyś wielka, lecz obecnie upadłą cywilizację z zepsucia, ponieważ posiadają wiedzę o niej i dzięki tej wiedzy z jednej strony rozumieja, że mogą ją , ulepszyć” (nawet jeśli takie „ulepszenie” miałoby odbywać się wbrew woli „nieoświeconych” Egipcjan oraz kosztem utraty ich suwerenności), z drugiej zaś - mają pojęcie o tym, jak tego dokonać (poprzez wyzwolenie tubylców spod typowo orientalnej despotycznej tyranii). „Podnieść kraj z jego obecnego barbarzyństwa do dawnej, klasycznej świetności; pouczyć (dla jego własnego dobra) o postępowaniu Zachodu; podporządkować siły wojskowe rozwijaniu przedsięwzięcia, którego celem było zdobywanie chwalebnej wiedzy w procesie politycznej dominacji nad Orientem; sformalizować Orient, nadać mu kształt, tożsamość i definicję z pełnym uznaniem dla jego miejsca w pamięci, jego wagi dla imperialnej strategii i jego »naturalnej« roli jako dodatku do Europy; [...] poczuć, że się jest Europejczykiem sprawującym władzę stosownie do wymagań orientalnej historii, czasu czy geografii; zinstytucjonalizować nowe dziedziny specjalistycznej wiedzy; dzielić, rozwijać, schematyzować, zestawiać w tablice, indeksować i rejestrować wszystko [...]; czynić z każdego zaobserwowanego szczegółu uogólnienie, a z każdego uogólnienia niezmienne prawo natury Orientu, jego temperamentu, mentalności, obyczajów czy typów jego mieszkańców, a nade wszystko przemieniać żywą rzeczywistość w teksty, aby ją posiąść [...]" ${ }^{\prime 80}$ - oto cele, które przyświecały XIX-wiecznym orientalistom.

Najważniejsze charakterystyki dyskursu orientalistycznego to: 1) tekstualność; 2) reprezentacjonizm; 3) esencjalizm oraz 4) zamkniętą wewnętrzną spójność. Pierwsza spośród wymienionych cech przejawia się w złudnym przekonaniu, iż obcy świat Wschodu można dobrze zrozumieć na podstawie prac literackich, że można w oparciu o nie odtworzyć jego zarówno całościowy, jak i neutralny (obiektywny) obraz. To właśnie ma na myśli E. Said twierdząc, iż Napoleon Bonaparte ,postrzegał Orient tylko w taki sposób, w jaki był on kodowany najpierw przez teksty klasyczne, a następnie przez badaczy-orientalistów, których wizja, oparta na tych tekstach, stanowiła użyteczny zamiennik każdego rzeczywistego zetknięcia się z prawdziwym Orientem"»1. Jak nietrudno zauważyć, kryją się tutaj dwa niebezpieczeństwa. Po pierwsze, nie sposób wyobrazić sobie tekst na tyle wszechstronny, aby był w stanie objać wszelkie możliwe aspekty i perspektywy opisu etnograficznego nawet niewielkiej zbiorowości. Po drugie, jak już zostało powiedziane, istota dyskursu orientalistycznego polegała nie tyle na

\footnotetext{
79 Ibidem, s. 71.

80 Ibidem, s. 136-137.

81 Ibidem, s. 130.
} 
wiernym odtwarzaniu Azji, ile na jej „oswajaniu”, czyli konstruowaniu wizji stawiającej bezpieczną przyswajalność opisu ponad jego rzetelnością.

Orientalizm nie był więc w stanie generować obiektywnej wiedzy o Wschodzie - stanowił on raczej zbiór reprezentacji - zestalonych i zobiektywizowanych w zbiorowej świadomości symbolicznych przedstawień, do których w upraszczający sposób sprowadzona została cała nieogarnięta różnorodność i inność orientu. Jak podkreśla autor, „orientalizm opiera się na zewnętrzności, czyli na tym, że orientalista, poeta lub uczony zmusza Orient do mówienia, opisuje go, odkrywa jego tajemnice Zachodowi. Nigdy natomiast nie interesuje się Orientem inaczej niż jako przyczyną swojej wypowiedzi. To, co mówi i pisze [...] ma udowadniać, że orientalista znajduje się poza Orientem zarówno egzystencjalnie, jak i moralnie. Głównym skutkiem takiej zewnętrzności jest oczywiście reprezentacja [... "82. Paradoksalnie więc, „orientalizm trzyma się z zasady z dala od Orientu: to, że w ogóle ma jakiś sens, zależy bardziej od Zachodu, a z kolei ten sens istnieje dzięki bogactwu zachodnich technik reprezentacji, które czynią Orient widocznym, jasnym i obecnym w dyskursie na jego temat. Reprezentacje, jakie związane są bezpośrednio z instytucjami, tradycjami, konwencjami i uzgodnionymi kodami porozumiewania się, a nie z odległym i nieokreślonym Orientem” ${ }^{83}$. Z tej perspektywy „Orient jest zatem sceną, na której zamyka się cały Wschód. $\mathrm{Na}$ tej scenie pojawiają się postaci, których rolą jest przedstawienie pewnej większej całości, z której pochodzą. Orient okazuje się więc nie nieograniczonym przedłużeniem europejskiego znanego świata, ale raczej zamkniętym polem, teatralną sceną przytwierdzoną do Europy. [...] W głębi tej orientalnej sceny kryje się niezwykły, kulturalny repertuar, którego pozycje przywołują bajecznie bogaty świat Wschodu: Sfinksa, Kleopatrę, Raj, Troję, Sodomę i Gomorę, [...] Mahometa i wielu innych; scenerie, w niektórych przypadkach tylko ich nazwy, na wpół wymyślone, na wpół znane; potwory, diabły, bohaterów, strachy, przyjemności i pragnienia" ${ }^{94}$, przez stulecia karmiące wyobraźnię zachodnich myślicieli i artystów pokroju Dantego, Miltona, Szekspira czy Cervantesa. ,Takie »obrazy« Orientu [...] są obrazami w tym sensie, że przedstawiają lub reprezentująjakiś ogromny byt - który bez nich pozostałby niemożliwie rozproszony - i umożliwiają jego ogarnięcie lub zrozumienie" ${ }^{85}$ poprzez skategoryzowanie i redukcjonistyczne, upraszczające sprowadzenie do niewielkiej grupy łatwych w interpretacji stereotypowych symboli. Zdaniem E. Saida, kluczową rolę w ugruntowaniu tej strategii odegrała wydana w 1697 r. Bibliotheque orientale Barthelamy'ego d'Herbelota - praca encyklopedyczna, stanowiąca próbę usystematyzowanie chaotycznego zbioru zachodnich przedstawień Wschodu w spójny, wewnętrznie uporządkowany system alfabetycznych haseł i definicji. ,Bibliotheque przekazuje nam zatem ideę siły i efektywności orientalizmu, które uświadamiają czytelnikowi, że odtąd, jeśli zechce się zmierzyć z Orientem, będzie musiał przebrnąć przez ustalenia i kodyfikacje stworzone przez orientalistów. Orient nie tylko zostaje przystosowany do moralnych potrzeb zachodniego chrześcijaństwa, ale również ograniczony przez zespół ujęć i osądów, które

\footnotetext{
82 Ibidem, s. 54-55.

83 Ibidem, s. 56.

84 Ibidem, s. 108

85 Ibidem, s. 112.
} 
odsyłają zachodniego czytelnika nie do orientalnych źródeł, na których podstawie mógłby dokonać weryfikacji czy poprawek, ale do prac innych orientalistów. [...] Krótko mówiąc, prawda staje się funkcją uczonego osądu [...]”86.

$\mathrm{Z}$ reprezentacjonizmem wiąże się trzecia fundamentalna cecha dyskursu orientalistycznego, a mianowicie - esencjalizm, konstytuowany przez założenie, iż - jak pisze Anwar Abdel Malek - ,powinno istnieć pewne sedno, istota [...] która tworzy niezbywalną i powszechną podstawę wszystkich rozpatrywanych istnień; ta istota jest równocześnie »historyczna«, ponieważ wywodzi się z początków historii, i zasadniczo ahistoryczna, ponieważ unieruchamia byty, »przedmioty badań«, w ramach ich niezbywalnej i niezmiennej swoistości [...]"87. Wszelkie reprezentacje Wschodu (Mahomet, Awerroes, Saladyn itd.) mają swoje arbitralnie ustalone i niezmienne miejsce (znaczenie, funkcję) w wielkiej kosmologii orientalistycznego przedstawienia - ono to właśnie powołuje je do istnienia i nadaje im znaczenie. W tym zamkniętym i samonapędzającym się systemie „obiekty są takie, jakie są, ponieważ są takie raz na zawsze, na całą wieczność, z przyczyn ontologicznych, których żadne badania empiryczne nie mogą usunąć lub zmienić” ${ }^{88}$. Dla orientalistów „historia, polityka i ekonomia nie mają znaczenia [...]: orientalizm, podobnie jak jego domniemany przedmiot badań, nie po-

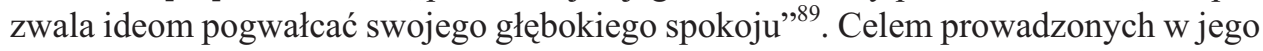
obrębie badań nie jest bowiem stworzenie rzetelnego opisu geograficzno-etnograficznego, lecz potwierdzenie apriorycznych hipotez wysnutych na kanwie poznanych uprzednio europejskich tekstów. „Empiryczne dane na temat Orientu prawie się nie liczą; liczy się tylko, a nawet jest elementem decydującym, orientalistyczna wizja w żaden sposób nie ograniczona do profesjonalnej nauki, ale raczej stanowiąca powszechną własność wszystkich, którzy na Zachodzie myśleli o Oriencie"'90. Ujmując to inaczej, orientalista jest zaprzeczeniem hermeneuty - zamiast bowiem odnosić się nieufnie względem dostępnych źródeł i dążyć do ich krytycznej weryfikacji, traktuje je z czołobitną wręcz nabożnością.

Zamknięta wewnętrzna spójność dyskursu orientalistycznego oznacza z kolei, iż - zarówno w wymiarze pojęciowym, jak i źródłowym czy instytucjonalnym - tworzy on system wprawdzie uporządkowany i zgodny, złożony z dobrze dopasowanych i funkcjonalnie powiązanych elementów, lecz jednocześnie w znacznym stopniu oderwany od rzeczywistości. Ów autonomiczny, konstruowany przez stulecie byt, żył własnym życiem, zgodnie ze swą swoista, immanentną logiką, bardziej sam dla siebie, aniżeli dla zrealizowania jakichś konkretnych celów poznawczych. Jak podkreśla E. Said, „każda praca na temat Orientu łączy się z innymi pracami, odbiorcami, instytucjami, z samym Orientem. Całość związków pomiędzy dziełami, odbiorcami i pewnymi określonymi aspektami Orientu tworzy zatem możliwą do przeanalizowania kreację [...] której sama obecność w czasie, w dyskursie, w instytucjach (szkołach, bibliote-

\footnotetext{
86 Ibidem, s. 113.

87 Cyt. za: ibidem, s. 151.

88 Ibidem, s. 117-118.

89 Ibidem, s. 164-165.

90 Ibidem, s. 116-117.
} 
kach, służbach dyplomatycznych) nadaje jej siłę i władzę"'11. Ważność poszczególnych składników takiej kreacji uporządkowana jest hierarchicznie - istnieją wyraźnie rozpoznawalne pozycje (Manners and Customs... Lane'a, Modern Egypt lorda Cromera, Description de l'Egypte, La Renaissance orientale Raymonda Schwaba, Bibliothe$q u e . .$. d'Herbelota, Voyage en Orient Gerarda de Nervala, Salammbo G. Flauberta, Dywan Zachodu i Wschodu oraz Mahometsgesang J. W. Goethego, Les Orientales Victora Hugo itp.), do których odwołują się wszyscy ci, którzy pragną przydać swym orientalistycznym refleksjom ,poznawczego” autorytetu. Jak nietrudno zauważyć, ich teksty nie uzyskują prawomocności w oparciu o relację wiążąca je z rzeczywistymi desygnatami, lecz na mocy powiązań z innymi, uprawomocnionymi już uprzednio tekstami. Powyższa uwaga tyczy się zresztą w równym stopniu poszczególnych tez i pojęć tworzących rdzeń orientalizmu. Uznanym kryterium prawdziwości twierdzenia o „oszustwie" Mahometa staje się w ten sposób wewnętrzna spójność dyskursywnego porządku oraz skłonność kolejnych pokoleń orientalistów do jego reprodukowania. „Jest ono powtarzane, Mahomet jest oszustem, przy każdym zaś powtórzeniu Mahomet staje się bardziej oszustem, a autor stwierdzenia zdobywa trochę więcej autorytetu" ${ }^{\prime 2}$.

Omówione na przykładzie orientalizmu cztery powyższe specyfiki: tekstualność (w jej szerokim, derridiańskim sensie), reprezentacjonizm, esencjalizm oraz zamknięta spójność wewnętrzna odnoszą się najprawdopodobniej do każdego istniejącego dyskursu.

$* * *$

Czerpiące obficie z tradycji poststrukturalizmu, studium dyskursu orientalistycznego Edwarda Saida wpisuje się bezpośrednio w specyfikę cultural studies, stanowiąc dziś jedno z kanonicznych osiagnięć tej dyscypliny. Jednocześnie rzuca ono nowe światło zarówno na historię stosunków międzynarodowych, jak i na szczególnie dziś aktualny problem postkolonializmu. Nawet jeśli ortodoksyjni internacjologowie sprzeciwiać się będą zaliczeniu Orientalizmu w poczet teoretycznej refleksji nad naturą systemu światowego, nie mogą oni zaprzeczyć, iż omówiona praca zwraca uwagę na ten wymiar dominacji, który dotychczas zdawał się umykać ich uwadze, a mianowicie - na rolę określonych typów wiedzy (tak naukowej, jak i potocznej) w kształtowaniu międzynarodowych stosunków politycznych. Podejście tradycyjnie proponowane przez realistów w dużej mierze redukuje kwestię kolonialnego imperializmu do pewnej struktury interesów, skorelowanej ze specyficznym rozkładem „twardej” potęgi w globalnej równowadze sił. Taka perspektywa czyni je jednocześnie zaskakująco bezradnym w dążeniu do zgłębienia istoty o wiele bardziej złożonych i w dużej mierze nieformalnych postkolonialnych relacji władzy. O krok do przodu posunęli się na owym „grząskim gruncie” dependyści (Samir Amin, Franz Fanon, Andre Gunder Frank) oraz postmarksowscy apologeci systemowej konceptualizacji Immanuela Wallersteina, zwracając uwagę na znaczenie reprodukowanych przez stulecia strukturalnych powiązań ekonomicznych w podtrzymywaniu „nieoficjalnej” dominacji dawnych

91 Ibidem, s 54.

92 Ibidem, s. 120. 
zachodnich metropolii nad pozornie tylko suwerennymi państwami niezachodnimi. Jednakże żadna z powyższych perspektyw nie przykłada należytej uwagi do analizy kulturowych wymiarów władzy - tych natomiast, co próbuje nam uzmysłowić E. Said, nie wolno lekceważyć, również w badaniach przestrzeni międzynarodowej. Jeśli jednostka ludzka rzeczywiście jest arystotelejskim „zwierzęciem politycznym” i nie istnieje poza społeczeństwem (a współcześnie nikt już raczej w to nie wątpi), to nie istnieje ona również poza kultura. Jak bowiem zauważa Antonina Kłoskowska, „oddziaływanie w świecie ludzkim jest prawie powszechnie przeniknięte kształtującym wpływem kulturowych norm i wzorów" ${ }^{93}$. Wtóruje jej antropolog Alfred Kroeber, zdaniem którego „dla każdej kultury społeczeństwo ludzkie stanowi warunek wstępny i konieczny, i odwrotnie - wszelkiemu społeczeństwu ludzkiemu towarzyszy kultura, zarówno jako jego wytwór, jak i warunek dalszego istnienia" ${ }^{94}$. Dlatego, w opinii Ralpha Lintona, „zespolenie pomiędzy jednostką, społeczeństwem i kulturą jest tak ścisłe, a interakcje tak ciagłe, że badacz, który by chciał zajmować się którymkolwiek z nich nie uwzględniając pozostałych obu, wkrótce musiałby się znaleźć w ślepej uliczce" ${ }^{\prime 95}$. Wniosek ów podzielają teoretycy cultural studies, twierdząc, iż pomijając wpływ podłoża społeczno-kulturowego, każda analiza sytuacji władczej razić będzie swą powierzchownością. Jest to najważniejszy postulat, jaki mogą przejąć od nich badacze stosunków międzynarodowych.

\section{STRESZCZENIE}

Główny cel niniejszego artykułu polega na ukazaniu, w jaki sposób podstawowe tezy tzw. studiów kulturowych mogą w sposób istotny przyczynić się do wzbogacenia perspektyw eksplanacyjnych teorii stosunkach międzynarodowych. Jako że dyscyplina ta koncentruje się na społeczno-kulturowych mechanizmach wytwarzania i reprodukowania władzy, otwiera przed badaczami systemu globalnego nowy wymiar analizy, lokowany dotychczas raczej poza głównym nurtem ich zainteresowań. Teoretycy studiów kulturowych dążą do ukazania, w jaki sposób kompleksowe i spójne struktury wiedzy, zwane formacjami dyskursywnymi determinują określony kształt rzeczywistości społecznej, w którym pewne grupy uzyskują pozycję uprzywilejowaną względem pozostałych. Kwestia ta została odniesiona do problematyki stosunków międzynarodowych na kartach Orientalizmu, głośnej pracy Edwarda Saida, łączącej fundamentalne założenia cultural studies z analizą kolonializmu i postkolonializmu. Stąd też dekonstrukcja zachodniego dyskursu orientalistycznego stanowi kluczowy element niniejszego artykułu.

Aby jednak spostrzeżenia E. Saida mogły zostać przedstawione wystarczająco czytelnie, muszą one zostać poprzedzone ogólną refleksją na temat samej istoty studiów kulturowych oraz relacji wiążących je konstruktywizmem poznawczym oraz szeroko pojmowanym postmodernizmem. Refleksji tej poświęcono pierwszą cześć artykułu. Część druga (środkowa) zawiera główne tezy teorii dyskursu sformułowane przez Jacquesa Derridę i Michela Foucaulta. Bez przybliżenia kategorii dyskursu nie sposób bowiem w pełni zrozumieć właściwej studiom kulturowym koncepcji władzy - władzy przez narzucenie i uprawomocnienie określonego opisu rzeczywistości. Ukazanie istoty owej kategorii jest również niezbędne do wyjaśnienia, w jaki

93 A. Kłoskowska, Kultura masowa. Krytyka i obrona, Warszawa 1980, s. 43.

94 A. Kroeber, Istota kultury, Warszawa 2002, s. 207.

95 R. Linton, Kulturowe podstawy osobowości, Warszawa 1975, s. 16. 
sposób, w opinii E. Saida, dyskurs orientalistyczny stał się instrumentem kolonialnej dominacji imperiów zachodnich nad obszarami i społeczeństwami orientu, czemu poświęcona jest ostatnia, trzecia część niniejszego tekstu.

\title{
CULTURAL STUDIES: NEW PERSPECTIVE FOR INTERNATIONAL RELATIONS?
}

\begin{abstract}
The main goal of this article is to show, in which way the main assumptions of cultural studies may be useful for development and enrichment the explanatory perspectives of international relations theory. Since that discipline concerns about social and cultural mechanisms, by which power is being created and reproduced, it opens in front of global system scholars a new analytical dimension, located so far rather outside to the main stream of their interests. Cultural studies theorists aspire to reveal, of how is it happening, that coherent and complex structures of knowledge, so called discoursive formations, determine certain forms of social reality, among which some groups obtain privileged position to the others. This case was related to international relations topic by Edward Said in Orientalism, a well-known and respected thesis, that combine the main assumptions of cultural studies with the matter of colonial and post-colonial domination. That is also why the deconstruction of western orientalistic discourse becomes the key aspect of this article.

To make E. Said's remarks clear enough, they need to be preceded, however, by general reflection about cultural studies as such and their connections with cognitive constructivism and widely grasped postmodernism. The first part of this article is dedicated to these thoughts. The second (middle) part contains basic arguments of discourse theory formulated by Jacques Derrida and Michel Foucault, because without them it would be impossible to understand a specific meaning of ,power" in cultural studies - the power by forcing and legalizing certain descriptions of reality. Showing the essence of this category seems to be indispensible to explain, in which way, according to E. Said's opinion, the orientalistic discourse became an instrument of western imperial domination over territories and societies of Orient. This problem will be considered in the last part of the article.
\end{abstract}


